\title{
Acrylamide: a Common Food Toxin Related to Physiological Functions and Health
}

\author{
M. SEMLA ${ }^{1}$, Z. GOC ${ }^{1}$, M. MARTINIAKOVÁ ${ }^{2}$, R. OMELKA ${ }^{2}$, G. FORMICKI ${ }^{1}$ \\ ${ }^{1}$ Pedagogical University of Cracow, Institute of Biology, Kraków, Poland, ${ }^{2}$ Constantine \\ the Philosopher University in Nitra, Faculty of Natural Sciences, Nitra, Slovak Republic
}

Received May 23, 2016

Accepted September 6, 2016

On-line December 16, 2016

\section{Summary}

Acrylamide (AA) is a highly reactive organic compound capable of polymerization to form polyacrylamide, which is commonly used throughout a variety of industries. Given its toxic effect on humans and animals, the last 20 years have seen an increased interest in research devoted to the AA. One of the main sources of $A A$ is food. $A A$ appears in heated food following the reaction between amino acids and reduced sugars. Large concentrations of AA can be found in popular staples such as coffee, bread or potato products. An average daily consumption of $A A$ is between $0.3-2.0 \mu \mathrm{g} / \mathrm{kg}$ b.w. Inhalation of acrylamide is related with occupational exposure. AA delivered with food is metabolized in the liver by cytochrome P450. AA biotransformation and elimination result in formation of toxic glycidamide (GA). Both, $\mathrm{AA}$ and $\mathrm{GA}$ can be involved in the coupling reaction with the reduced glutathione (GSH) forming glutathione conjugates which are excreted with urine. Biotransformation of AA leads to the disturbance in the redox balance. Numerous research proved that AA and GA have significant influence on physiological functions including signal propagation in peripheral nerves, enzymatic and hormonal regulation, functions of muscles, reproduction etc. In addition $\mathrm{AA}$ and $\mathrm{GA}$ show neurotoxic, genotoxic and cancerogenic properties. In 1994, International Agency for Research on Cancer (IARC) classified acrylamide as a potentially carcinogenic substance to human.

\section{Key words}

Acrylamide • Neurotoxicity • Genotoxicity • Reproductive toxicity - Oxidative stress

\section{Corresponding author}

G. Formicki, Institute of Biology, Pedagogical University of Cracow, Podbrzezie 3, 31-054 Kraków, Poland. E-mail: gformi@gmail.com

\section{Introduction}

Food should deliver all the ingredients necessary for the organism to function properly. Organic and inorganic compounds present in food are used by the organism as energetic, regulatory and/or building substances. Unfortunately, food consumed by people is often a source of harmful substances. Acrylamide (AA) is one of the most common toxins in food. It occurs in food containing high concentrations of hydrocarbons subjected to high temperature (Mottram et al. 2002). High concentration of acrylamide may be found in food products such as potato chips, fried potatoes, cornflakes or bread. Thus acrylamide is present in every day diet of most people. To make matters worse, some of the products containing acrylamide are attractive to children and young people.

In 2001, the Scientific Committee on Toxicity, Ecotoxicity and the Environment demonstrated its neurotoxicity, genotoxicity, carcinogenicity and reproductive toxicity (Keramat et al. 2011, Carere 2006). Toxic effects of acrylamide are mediated by the formation of genotoxic metabolites, oxidative stress, affected propagation of neural signals, ultrastructural and histological defects in central neural system (LoPachin 2004, El-Sayyad et al. 2011, Pingot et al. 2013). The 
International Agency for Research on Cancer (IARC 1994) classified acrylamide as potentially carcinogenic substance to human.

Most of the mechanisms of AA toxicity are well recognized. Nonetheless some aspects of acrylamide toxicity remain still unclear. First of all, the doses used in animal experiments are much higher than mean acrylamide intake in food. Thus it is not known whether acrylamide ingested with everyday diet pose real risk to consumers' health. On the other hand, the known incidences of occupational exposure were probably related with the intoxication with very high acrylamide doses (Pennisi et al. 2013). The studies conducted in chemical plants revealed that personal breathing zone air samples contained up to $984 \mu \mathrm{g}$ of AA per $\mathrm{m}^{3}$ of air. Acrylamide and polyacrylamide production operators had hemoglobin AA adducts in the concentration up to $1884 \mathrm{pmol} / \mathrm{g}$, whereas hemoglobin AA adducts level in administrative workers was $97.9 \mathrm{pmol} / \mathrm{g}$ (Moorman et al. 2012). It is still unclear whether toxic effects of chronic exposure to acrylamide may accumulate in the organism in the long term. Very little is known about the risk of fetal exposure to AA and their potential effects to the prenatal and postnatal development. Thus the aim of this article is to bring together data from different studies in order to analyze the risk of exposure to AA and related health risks.

\section{Acrylamide in food}

Acrylamide $\left(\mathrm{CH}_{2}=\mathrm{CH}-\mathrm{CO}-\mathrm{NH}_{2}\right.$, according to IUPAC: 2-propenamid) is a highly reactive, organic, white and crystal substance, with molecular weight of $71.08 \mathrm{~g}$ (Żyżelewicz et al. 2010). AA is a polar substance which easily dissolves in water or other polar solvents, e.g. in methanol or ethanol (Jankowska et al. 2009). High reactivity of AA is connected with the double bond and amide group. The compound may create hydrogen bonds and can react both with amide and vinyl groups (Girma et al. 2005, Żyżelewicz et al. 2010). Acrylamide is polymerized under the influence of temperature and UV radiation. These reactions result in creation of new chemical compounds called polyacrylamides.

Recent years revealed a considerable increase in investigation of acrylamide as a potentially dangerous substance to people. In early 2000s, Swedish researchers proved that certain foods might contain large concentrations of acrylamide (Lofstedt 2003). The research by Tareke et al. (2002) indicated that food processing has influence on acrylamide formation. The factors influencing the occurrence of AA in the food are: temperature, exposure time to high temperature, the amino acids content and their types and the content of carbohydrates in the food (Becalski et al. 2003, Konings et al. 2003). AA is formed during frying, deep frying and baking foods rich in carbohydrates and especially in amino acid - asparagine. High concentrations of AA are found in processed foods like: chips $(50-3500 \mu \mathrm{g} / \mathrm{kg})$, frites $(170-2287 \mu \mathrm{g} / \mathrm{kg})$, coffee $(170-350 \mu \mathrm{g} / \mathrm{kg})$, bread (70-430 $\mu \mathrm{g} / \mathrm{kg}$ ) or corn flakes (30-1400 $\mu \mathrm{g} / \mathrm{kg}$ ) (Friedman 2003). Acrylamide concentrations in selected foodstuffs together with methods of measurements of acrylamide concentration in food are presented in Table 1.

The mechanism of AA formation in food has not been clearly described yet. Numerous research has shown only hypothetical ways in which AA is being formed in comestible products (Edegaard et al. 2008, Mestdagh et al. 2008). Most of the research point to asparagine presence as a significant factor contributing to AA formation (Zhang et al. 2009, Taeymans et al. 2004). The reaction between glucose (reducing sugar) and asparagine gives a product responsible for the food's flavor and color. This reaction is known as a Millard's reaction and it has a higher rate at the temperature exceeding $120{ }^{\circ} \mathrm{C}$ (Friedman 2003, Tareke et al. 2002). The content of AA increases considerably during frying, grilling and roasting. Popular foodstuffs such as coffee, high-in-starch potato products and cereal products contain large amounts of AA (Claus et al. 2008, TajnerCzopek et al. 2012). People are also exposed to harmful effects of AA by consuming natural unprocessed products rich in asparagines, including asparagus, cocoa beans or cereals (Rachwał and Nebesny 2012). According to the European Food Safety Authority (EFSA) report, the level of AA in food ranges from under $30 \mu \mathrm{g} / \mathrm{kg}$ to $4700 \mu \mathrm{g} / \mathrm{kg}$, depending on the product (EFSA 2009, Mojska and Gielecińska 2012). Research also shows that exposure to AA varies and depends mainly on the population, age of consumers and their eating preferences. In European populations, mean daily intake of acrylamide goes from 0.14 to $1.31 \mu \mathrm{g} / \mathrm{kg}$ body weight. Similar mean intake $(0.43-1.1 \mu \mathrm{g} / \mathrm{kg}$ body weight per day) was indicated in the United States (Dybing and Sanner 2003). The research conducted in Kraków, Poland by Jankowska et al. (2009) indicated that AA was excessively consumed by children and teenagers. Among children and adults, bread - a product eaten on a daily basis, is the main source of AA. Other Polish research indicated that 
Table 1. Acrylamide content in analyzed products.

\begin{tabular}{|c|c|c|c|c|c|}
\hline Author & $\begin{array}{c}\text { Number } \\
\text { of food } \\
\text { samples }\end{array}$ & $\begin{array}{c}\text { Analysis } \\
\text { of acrylamide } \\
\text { in food }\end{array}$ & $\begin{array}{l}\text { Acrylamide } \\
\text { content }\end{array}$ & $\begin{array}{l}\text { Products with the } \\
\text { highest acrylamide } \\
\text { content }\end{array}$ & $\begin{array}{c}\text { Highest mean } \\
\text { acrylamide } \\
\text { content }(\mu \mathrm{g} / \mathrm{kg})\end{array}$ \\
\hline \multirow[t]{4}{*}{ Claeys et al. 2010} & \multirow[t]{4}{*}{1725} & \multirow[t]{4}{*}{ LC-MS } & \multirow{4}{*}{$\begin{array}{c}34-2814 \mu \mathrm{g} / \mathrm{kg} \\
(\text { mean) }\end{array}$} & Coffee substitute & $2814 \pm 1045$ \\
\hline & & & & Instant coffee & $694 \pm 81$ \\
\hline & & & & Potato crisps & $525 \pm 477$ \\
\hline & & & & Gingerbread & $431 \pm 455$ \\
\hline \multirow[t]{4}{*}{ Sirot et al. 2012} & \multirow[t]{4}{*}{192} & \multirow[t]{4}{*}{ LC-MS } & \multirow{4}{*}{$\begin{array}{l}2-954 \mu \mathrm{g} / \mathrm{kg} \\
\text { (range) }\end{array}$} & Potato chips & $954 \pm 240$ \\
\hline & & & & French fries & $724 \pm 358$ \\
\hline & & & & Cocktail biscuits (salted) & $697 \pm 430$ \\
\hline & & & & Chocolate biscuits & $139 \pm 100$ \\
\hline \multirow[t]{4}{*}{ Konings et al. 2003} & \multirow[t]{4}{*}{341} & \multirow[t]{4}{*}{ LC-MS-MS } & \multirow{4}{*}{$\begin{array}{c}<30-3100 \mu \mathrm{g} / \mathrm{kg} \\
\quad \text { (range) }\end{array}$} & Potato crisps & $1249 \pm 656$ \\
\hline & & & & Cocktail snacks & $1060 \pm 950$ \\
\hline & & & & Gingerbread & $890 \pm 393$ \\
\hline & & & & Chips (deep-fried) & $351 \pm 297$ \\
\hline \multirow{2}{*}{$\begin{array}{l}\text { Mojska and } \\
\text { Gielecińska } 2012\end{array}$} & \multirow[t]{2}{*}{111} & \multirow{2}{*}{$\begin{array}{c}\text { GCQ-MS/MS } \\
\text { LC-MS/MS }\end{array}$} & \multirow{2}{*}{$\begin{array}{c}2-516 \mu \mathrm{g} / \mathrm{kg} \\
\text { (range) }\end{array}$} & Follow-on formula & $73 \pm 78$ \\
\hline & & & & Infant biscuits & $219 \pm 139$ \\
\hline
\end{tabular}

LC-MS - liquid chromatography-mass spectrometry, LC-MS-MS - liquid chromatography tandem mass spectrometry, GCQ-MS/MS - gas chromatography with tandem mass spectrometry, LC-MS/MS - liquid chromatography with tandem mass spectrometry.

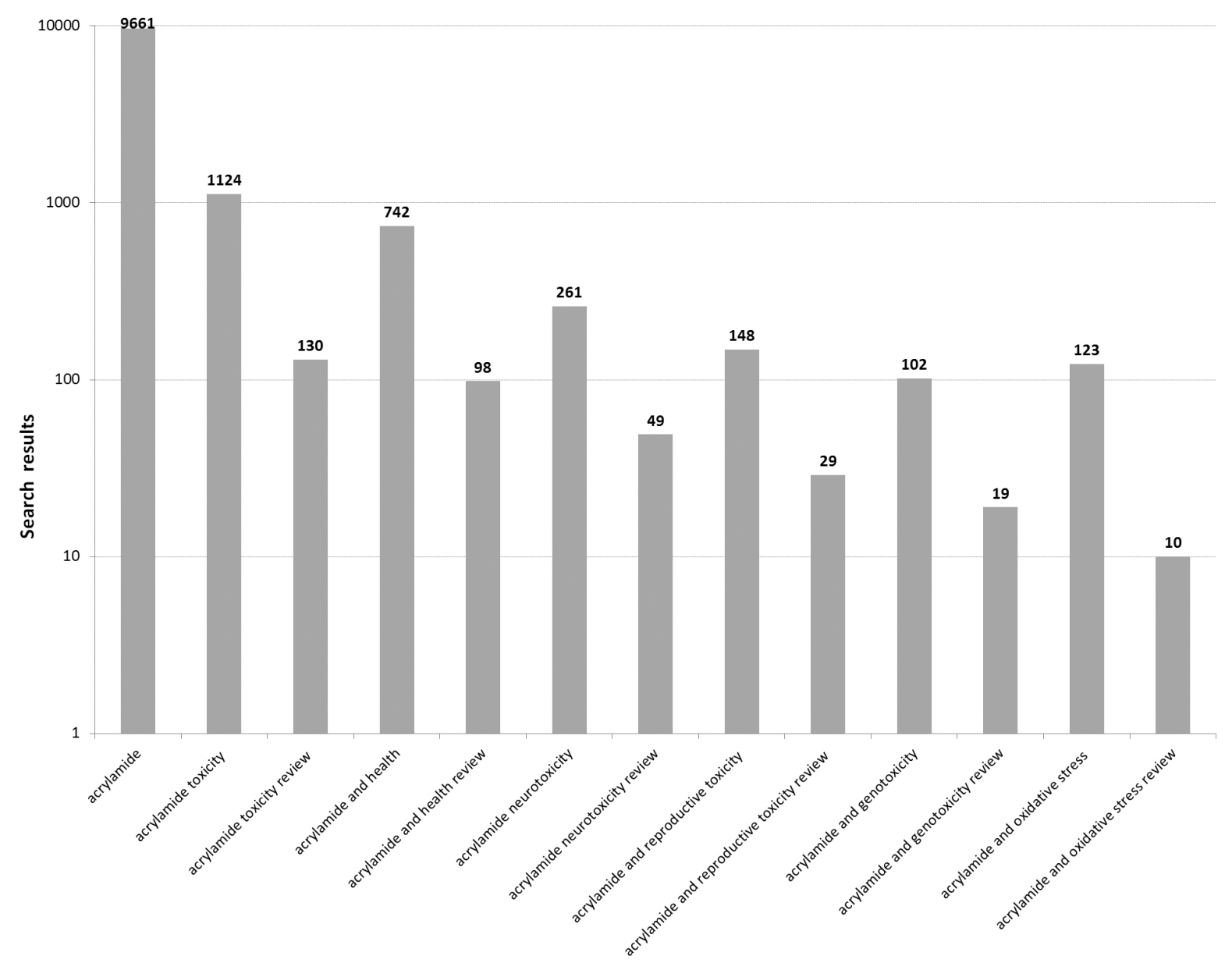

Fig. 1. Acrylamide studies according to PubMed (data from 1958 till 2016-08-23). 
Table 2. Exposure of human population to acrylamide.

\begin{tabular}{|c|c|c|c|c|c|}
\hline Authors & Method used & $\begin{array}{l}\text { Population } \\
\text { (n, total } \\
\text { population) }\end{array}$ & $\begin{array}{c}\text { Age } \\
\text { years/months } \\
\text { (n, group size) }\end{array}$ & $\begin{array}{l}\text { Daily doses } \\
\text { ingested }\end{array}$ & $\begin{array}{l}\text { Contribution of food in } \\
\text { daily acrylamide } \\
\text { exposure }\end{array}$ \\
\hline \multirow[t]{5}{*}{$\begin{array}{l}\text { Zając et al. } \\
2013\end{array}$} & \multirow[t]{5}{*}{$\begin{array}{l}\text { Semi-quantitative } \\
\text { food frequency } \\
\text { questionnaire }\end{array}$} & \multirow[t]{5}{*}{$\begin{array}{l}\text { Polish } \\
(n=1470)\end{array}$} & $\begin{array}{l}6-12 \text { years } \\
(n=300)\end{array}$ & $\begin{array}{l}\text { mean: } \\
1.51 \mu \mathrm{g} / \mathrm{kg} \text { b.w. }\end{array}$ & $\begin{array}{l}\text { Baked goods } 42 \% \\
\text { Crisps } 25 \% \\
\text { Cookies } 14 \%\end{array}$ \\
\hline & & & $\begin{array}{l}13-19 \text { years } \\
(\mathrm{n}=296)\end{array}$ & $\begin{array}{l}\text { mean: } \\
0.89 \mu \mathrm{g} / \mathrm{kg} \text { b.w. }\end{array}$ & $\begin{array}{l}\text { Baked goods } 46 \% \\
\text { Cookies } 25 \% \\
\text { French fries } 12 \% \\
\end{array}$ \\
\hline & & & $\begin{array}{l}\text { 20-30 years } \\
(n=296)\end{array}$ & $\begin{array}{l}\text { mean: } \\
0.61 \mu \mathrm{g} / \mathrm{kg} \text { b.w. }\end{array}$ & $\begin{array}{l}\text { Baked goods } 55 \% \\
\text { Cookies } 15 \% \\
\text { Coffee } 9 \%\end{array}$ \\
\hline & & & $\begin{array}{l}31-41 \text { years } \\
(n=278)\end{array}$ & $\begin{array}{l}\text { mean: } \\
0.56 \mu \mathrm{g} / \mathrm{kg} \text { b.w. }\end{array}$ & $\begin{array}{l}\text { Baked goods } 55 \% \\
\text { Coffee } 16 \% \\
\text { Cookies } 15 \%\end{array}$ \\
\hline & & & $\begin{array}{l}\text { 42-60 years } \\
(n=300)\end{array}$ & $\begin{array}{l}\text { mean: } \\
0.67 \mu \mathrm{g} / \mathrm{kg} \text { b.w. }\end{array}$ & $\begin{array}{l}\text { Baked goods } 38 \% \\
\text { Crisps } 22 \% \\
\text { Coffee } 16 \%\end{array}$ \\
\hline $\begin{array}{l}\text { Claeys et al. } \\
2010\end{array}$ & $\begin{array}{l}\text { Probabilistic approach } \\
\text { 'Monte Carlo Risk } \\
\text { Analysis Programme' }\end{array}$ & $\begin{array}{l}\text { Belgium } \\
(n=662)\end{array}$ & $\begin{array}{l}2.5-6.5 \text { years } \\
(n=662)\end{array}$ & $\begin{array}{l}\text { mean: } \\
0.72 \mu \mathrm{g} / \mathrm{kg} \text { b.w. }\end{array}$ & $\begin{array}{l}\text { Biscuits } 26 \% \\
\text { French fries } 25 \% \\
\text { Bread \& rolls } 20.2 \%\end{array}$ \\
\hline $\mathrm{BfR} * 2003$ & Questionnaire & $\begin{array}{l}\text { German } \\
(\mathrm{n}=1085)\end{array}$ & $\begin{array}{l}15-18 \text { years } \\
(n=1085)\end{array}$ & $\begin{array}{l}\text { mean: } \\
1.10 \mu \mathrm{g} / \mathrm{kg} \text { b.w. }\end{array}$ & $\begin{array}{l}\text { Toast } 9 \% \\
\text { Fried potatoes } 6 \%\end{array}$ \\
\hline \multirow[t]{9}{*}{$\mathrm{BCS} * * 2012$} & \multirow{9}{*}{$\begin{array}{l}\text { Probabilistic dietary } \\
\text { exposure to } \\
\text { acrylamide based on } \\
\text { the AA measured in } \\
\text { samples of each food } \\
\text { along with individual } \\
\text { consumption data }\end{array}$} & \multirow[t]{9}{*}{$\begin{array}{l}\text { Canada } \\
(\mathrm{n}=32088)\end{array}$} & $\begin{array}{l}<1 \text { year } \\
(n=279)\end{array}$ & $\begin{array}{l}\text { mean: } \\
0.211 \mu \mathrm{g} / \mathrm{kg} \text { b.w. }\end{array}$ & - \\
\hline & & & $\begin{array}{l}1-3 \text { years } \\
(n=2096)\end{array}$ & $\begin{array}{l}\text { mean: } \\
0.609 \mu \mathrm{g} / \mathrm{kg} \text { b.w. }\end{array}$ & \multirow{8}{*}{$\begin{array}{l}\text { French fries } 30.0 \% \\
\text { Snack chips } 14.9 \% \\
\text { Coffee } 12.3 \%\end{array}$} \\
\hline & & & $\begin{array}{l}4-8 \text { years } \\
(n=3047)\end{array}$ & $\begin{array}{l}\text { mean: } \\
0.597 \mu \mathrm{g} / \mathrm{kg} \text { b.w. }\end{array}$ & \\
\hline & & & $\begin{array}{l}9-13 \text { years } \\
(\mathrm{n}=3883)\end{array}$ & $\begin{array}{l}\text { mean: } \\
0.442 \mu \mathrm{g} / \mathrm{kg} \text { b.w. }\end{array}$ & \\
\hline & & & $\begin{array}{l}14-18 \text { years } \\
(n=4423)\end{array}$ & $\begin{array}{l}\text { mean: } \\
0.356 \mu \mathrm{g} / \mathrm{kg} \text { b.w. }\end{array}$ & \\
\hline & & & $\begin{array}{l}19-30 \text { years } \\
(n=3713)\end{array}$ & $\begin{array}{l}\text { mean: } \\
0.288 \mu \mathrm{g} / \mathrm{kg} \text { b.w. }\end{array}$ & \\
\hline & & & $\begin{array}{l}31-50 \text { years } \\
(\mathrm{n}=5125)\end{array}$ & $\begin{array}{l}\text { mean: } \\
0.248 \mu \mathrm{g} / \mathrm{kg} \text { b.w. }\end{array}$ & \\
\hline & & & $\begin{array}{l}51-70 \text { years } \\
(n=5533)\end{array}$ & $\begin{array}{l}\text { mean: } \\
0.187 \mu \mathrm{g} / \mathrm{kg} \text { b.w. }\end{array}$ & \\
\hline & & & $\begin{array}{l}\geq 71 \text { years } \\
(n=3989)\end{array}$ & $\begin{array}{l}\text { mean: } \\
0.157 \mu \mathrm{g} / \mathrm{kg} \text { b.w. }\end{array}$ & \\
\hline \multirow[t]{2}{*}{$\begin{array}{l}\text { Sirot et al. } \\
2012\end{array}$} & \multirow{2}{*}{$\begin{array}{l}\text { Probabilistic } \\
\text { approach on the basis } \\
\text { of the weekly food } \\
\text { consumption }\end{array}$} & \multirow[t]{2}{*}{$\begin{array}{l}\text { French } \\
(n=336)\end{array}$} & $\begin{array}{l}18-79 \text { years } \\
(n=191)\end{array}$ & $\begin{array}{l}\text { mean: } \\
0.43 \pm 0.33 \mu \mathrm{g} / \mathrm{kg} \\
\text { b.w. }\end{array}$ & $\begin{array}{l}\text { French fries } 44.8 \% \\
\text { Coffee } 29.5 \% \\
\text { Biscuits } 9.4 \%\end{array}$ \\
\hline & & & $\begin{array}{l}3-17 \text { years } \\
(n=145)\end{array}$ & $\begin{array}{l}\text { mean: } \\
0.69 \pm 0.58 \mu \mathrm{g} / \mathrm{kg} \\
\text { b.w. }\end{array}$ & $\begin{array}{l}\text { French fries } 60.8 \% \\
\text { Biscuits } 18.8 \% \\
\text { Cakes and other sweetened } \\
\text { pastry } 3.3 \%\end{array}$ \\
\hline
\end{tabular}




\begin{tabular}{|c|c|c|c|c|c|}
\hline \multirow[t]{3}{*}{$\begin{array}{l}\text { Konings et } \\
\text { al. } 2003\end{array}$} & \multirow[t]{3}{*}{$\begin{array}{l}\text { Probabilistic approach } \\
\text { 'Monte Carlo Risk } \\
\text { Analysis Programme' }\end{array}$} & \multirow[t]{3}{*}{$\begin{array}{l}\text { Dutch } \\
(n=6250)\end{array}$} & $\begin{array}{l}1-6 \text { years } \\
\text { (n, not given) }\end{array}$ & $\begin{array}{l}\text { mean: } \\
1.04 \mu \mathrm{g} / \mathrm{kg} \text { b.w. }\end{array}$ & $\begin{array}{l}\text { Crisps } 40 \% \\
\text { Dutch spiced cake } 20 \% \\
\text { Chips and comparable } \\
\text { products } 18 \% \\
\end{array}$ \\
\hline & & & $\begin{array}{l}\text { 7-18 years } \\
\text { (n, not given) }\end{array}$ & $\begin{array}{l}\text { mean: } \\
0.71 \mu \mathrm{g} / \mathrm{kg} \text { b.w. }\end{array}$ & $\begin{array}{l}\text { Crisps } 46 \% \\
\text { Dutch spiced cake } 23 \% \\
\text { Chips and comparable } \\
\text { products } 11 \% \\
\end{array}$ \\
\hline & & & $\begin{array}{l}1-97 \text { years } \\
(\mathrm{n}=6250)\end{array}$ & $\begin{array}{l}\text { mean: } \\
0.48 \mu \mathrm{g} / \mathrm{kg} \text { b.w. }\end{array}$ & $\begin{array}{l}\text { Crisps } 31 \% \\
\text { Chips and comparable } \\
\text { products } 21 \% \\
\text { Dutch spiced cake } 16 \%\end{array}$ \\
\hline \multirow[t]{3}{*}{$\begin{array}{l}\text { Dybing and } \\
\text { Sanner } 2003\end{array}$} & $\begin{array}{l}\text { Food Frequency } \\
\text { Questionnaire (FFQ) }\end{array}$ & $\begin{array}{l}\text { Norway } \\
(n=2672)\end{array}$ & $\begin{array}{l}16-79 \text { years } \\
(n=2672)\end{array}$ & $\begin{array}{l}\text { mean: } \\
0.46-0.49 \mu \mathrm{g} / \mathrm{kg} \\
\text { b.w. }\end{array}$ & $\begin{array}{l}\text { Coffee } 28-28.6 \% \\
\text { Potato crisps } 17.6-17.4 \% \\
\text { Soft bread } 13.0-11.9 \% \\
\end{array}$ \\
\hline & \multirow{2}{*}{$\begin{array}{l}\text { Probabilistic } \\
\text { approach based on } \\
\text { UNGKOST } 2000 \\
\text { data }\end{array}$} & \multirow[t]{2}{*}{$\begin{array}{l}\text { Norway } \\
(n=6736)\end{array}$} & $\begin{array}{l}9 \text { years } \\
(\mathrm{n}=2957)\end{array}$ & $\begin{array}{l}\text { mean: } \\
0.32-0.36 \mu \mathrm{g} / \mathrm{kg} \\
\text { b.w. }\end{array}$ & \multirow[t]{2}{*}{$\begin{array}{l}\text { Potato crisps, butter } \\
\text { biscuits, sweet biscuits } \\
55-65 \%\end{array}$} \\
\hline & & & $\begin{array}{l}13 \text { years } \\
(\mathrm{n}=3779)\end{array}$ & $\begin{array}{l}\text { mean: } \\
0.49-0.52 \mu \mathrm{g} / \mathrm{kg} \\
\text { b.w. }\end{array}$ & \\
\hline \multirow{5}{*}{$\begin{array}{l}\text { Mojska and } \\
\text { Gielecińska } \\
2012\end{array}$} & \multirow{5}{*}{$\begin{array}{l}\text { Probabilistic } \\
\text { approach based on } \\
\text { the theoretical } \\
\text { number of food } \\
\text { portions }\end{array}$} & \multirow[t]{5}{*}{$\begin{array}{l}\text { Polish } \\
\text { (n, not given) }\end{array}$} & $\begin{array}{l}6 \text { month } \\
(\mathrm{n}, \text { not given })\end{array}$ & $\begin{array}{l}\text { mean: } 17.46 \mu \mathrm{g} / \\
\text { person/day }\end{array}$ & \begin{tabular}{|l|} 
Jarred baby food $56.7 \%$ \\
Follow-on formula $43.3 \%$ \\
\end{tabular} \\
\hline & & & $\begin{array}{l}7 \text { month } \\
\text { ( } n, \text { not given) }\end{array}$ & $\begin{array}{l}\text { mean: } \\
20.87 \mu \mathrm{g} / \\
\text { person/day }\end{array}$ & $\begin{array}{l}\text { Jarred baby food } 52.7 \% \\
\text { Follow-on formula } 27.2 \%\end{array}$ \\
\hline & & & $\begin{array}{l}8 \text { month } \\
\text { ( } n, \text { not given) }\end{array}$ & $\begin{array}{l}\text { mean: } \\
21.65 \mu \mathrm{g} / \\
\text { person/day }\end{array}$ & $\begin{array}{l}\text { Jarred baby food } 50.8 \% \\
\text { Follow-on formula } 26.2 \%\end{array}$ \\
\hline & & & $\begin{array}{l}9 \text { month } \\
\text { ( } \mathrm{n}, \text { not given) }\end{array}$ & $\begin{array}{l}\text { mean: } \\
29.06 \mu \mathrm{g} / \\
\text { person/day }\end{array}$ & $\begin{array}{l}\text { Jarred baby food } 37.9 \% \\
\text { Follow-on formula } 21.7 \%\end{array}$ \\
\hline & & & $\begin{array}{l}\text { 10-12 months } \\
\text { (n, not given) }\end{array}$ & $\begin{array}{l}\text { mean: } \\
38.05 \mu \mathrm{g} / \\
\text { person/day }\end{array}$ & $\begin{array}{l}\text { Jarred baby food } 55.2 \% \\
\text { Infant cereals } 18.2 \%\end{array}$ \\
\hline \multirow[t]{4}{*}{$\begin{array}{l}\text { Brantsæter } \\
\text { et al. } 2008\end{array}$} & $\begin{array}{l}\text { Probabilistic data } \\
\text { based on the food } \\
\text { frequency } \\
\text { questionnaire (FFQ) }\end{array}$ & \multirow{4}{*}{$\begin{array}{l}\text { Norwegian, } \\
\text { pregnant } \\
\text { women } \\
\text { (n=19, } \\
\text { age } 23-44)\end{array}$} & $\mathrm{n}=19$ & $\begin{array}{l}\text { median: } \\
33.7 \mu \mathrm{g} / \text { person }\end{array}$ & \multirow{4}{*}{$\begin{array}{l}\text { Crispbread 10-22 \% } \\
\text { Potato crisps 14-16\% } \\
\text { Bread 8-11\% } \\
\text { Biscuits 5-10\% } \\
\text { Breakfast cereals 6-8 \% }\end{array}$} \\
\hline & $\begin{array}{l}\text { Probabilistic data } \\
\text { based on the food } \\
\text { diary (FD) }\end{array}$ & & $\mathrm{n}=19$ & $\begin{array}{l}\text { median: } \\
28.5 \mu \mathrm{g} / \text { person }\end{array}$ & \\
\hline & $\begin{array}{l}\text { Probabilistic data } \\
\text { based on the AA } \\
\text { metabolite } \\
\text { concentration in urine } \\
\text { (non-smokers) }\end{array}$ & & $\mathrm{n}=16$ & $\begin{array}{l}\text { median: } \\
20.3 \mu \mathrm{g} / \text { person }\end{array}$ & \\
\hline & $\begin{array}{l}\text { Probabilistic data } \\
\text { based on the } \\
\text { metabolite } \\
\text { concentration in urine } \\
\text { (smokers) }\end{array}$ & & $\mathrm{n}=3$ & $\begin{array}{l}\text { median: } \\
91.1 \mu \mathrm{g} / \text { person }\end{array}$ & \\
\hline
\end{tabular}

* Federal Institute for Risk Assessment (BfR), ** Bureau of Chemical Safety, Food Directorate, Health Products and Food Branch (BCS). 
an average AA consumption in children aged 1-6 years was about $0.47 \mu \mathrm{g} / \mathrm{kg}$ b.w. per day and among children aged 7-18 years it was $0.34 \mu \mathrm{g} / \mathrm{kg}$ b.w. per day (Mojska and Gielecińska 2012). Maximum intake of acrylamide reaching 7.9 and $8.1 \mu \mathrm{g} / \mathrm{kg}$ b.w. per day was estimated in 13 years old Norwegian boys and girls respectively (Dybing and Sanner 2003). Food-related exposure of human populations to acrylamide together with methods used for estimation of exposure levels are listed in Table 2. Analysis of acrylamide studies is given in Figure 1.

\section{Other kinds of exposure to acrylamide}

Polyacrylamides are widely used in the industry for water treatment (as flocculator), component of mortars, adhesives, dyes or in the textile and cosmetic industries. Furthermore, polyacrylamide is used in laboratories, e.g. gel electrophoresis (Friedman 2003). AA is used for selective modification of protein's sulfhydryl groups ( $\mathrm{SH})$ and the electrophoretic separation of nucleic acids and proteins in the laboratories (Szczerbina 2005).

Initially, polyacrylamide added to fertilizers or used as coagulant for water treatment was claimed as the main source of AA (Szczerbina 2005, Żyżelewicz et al. 2010). Cosmetic, tobacco industry and plastics were indicated as the other sources of AA (Szczerbina 2005).

Occupational exposure mostly affects chemical plant workers, laboratory workers, construction industry workers, miners or workers of coal preparation plants (Pennisi et al. 2013). The most publicized incidences of exposure include exposure to ground water contaminated with acrylamide and N-methyloacrylamide in tunnel workers in Norway (Kjuus et al. 2004, Goffeng et al. 2008) or exposures to aqueous solution of acrylamide in workers of chemical manufactories in China (He et al. 1989). Typical symptoms of exposure are manifested by paresthesia of the extremities, muscle weakness, ataxia, increased sweating. Most of them result from peripheral neuropathy. In some cases impaired vision was diagnosed (Pennisi et al. 2013). Interestingly, similar neurological effects were indicated in laboratory studies in rats after 4 weeks of every third day exposures to doses of acrylamide as high as $40 \mathrm{mg} / \mathrm{kg}$ b.w. (Zhu et al. 2008).

High exposure to acrylamide occurs in tobacco smokers. Total amount of acrylamide in the smoke from a single cigarette is around $1 \mu \mathrm{g}$ or higher. Cigarettes and other tobacco products like snuff, tobacco sticks or strips contain acrylamide in the range from below 100 to $367 \mathrm{ng} / \mathrm{g}$ (Moldoveanu and Gerardi 2011). Thus tobacco related acrylamide intake depends on the number of cigarettes smoked per day and/or the type of tobacco product consumed. Measurements of the hemoglobin adducts with acrylamide suggest several times higher exposure to AA in tobacco smokers than in non-smokers (Schettgen et al. 2004). Median value of acrylamide intake in smoking pregnant women was estimated in the level of $91.1 \mu \mathrm{g} /$ day (Brantsæter et al. 2008).

\section{Absorption, metabolism and distribution of acrylamide}

There are three ways by which AA is transmitted into the body: digestive system, respiratory system (e.g. cigarette smoke) and skin absorption (e.g. cosmetics) (Carere 2006, Vesper et al. 2007). Irrespective of route, exposure to acrylamide rapidly occurs in blood plasma with a peak concentration of $60-90 \mathrm{~min}$ in rats. Its epoxide form occurs later. In rats, the peak concentration of GA is delayed by about $100 \mathrm{~min}$ in relation to AA plasma peak (Barber et al. 2001). Both $\mathrm{AA}$ and glycidamide may create adducts with hemoglobin following the reaction with sulfhydryl groups. The level of adducts is often used as indicator of exposure to acrylamide as their formation is proportional to the acrylamide dose ingested, inhaled or absorbed through the skin (Pingot et al. 2013, Tareke et al. 2008, Vikström et al. 2012). Relatively large concentrations of $\mathrm{AA}$ and GA are distributed into muscle and neural tissues (Barber et al. 2001). AA delivered by the oral route is metabolized in the liver. The biotransformation takes place with the cytochrome P450. As a result of acrylamide biotransformation, its epoxide form glycidamide (2,3-epoksypropan amide) is formed (Tareke et al. 2008). During the second phase of biotransformation, AA and glycidamide (GA) are coupled with reduced glutathione (GSH) by enzymes from the family of glutathione S-transferase (GST) which leads to formation the glutathione conjugates (Friedman 2003). The final products of the glutathione conjugates reaction are the derivatives of $\mathrm{N}$-acetylcysteine excreted in urine (Pingot et al. 2013). As a result of reaction with GSH, $\mathrm{AA}$ and its derivatives lose their toxic properties and may be more easily excreted from the organism. Only about $50 \%$ of the AA daily dose is depurated from the organism, mainly in the urine (EFSA 2008). The half-life of AA in human organism is $2-7 \mathrm{~h}$ which shows how 
slowly this substance is being removed from the body (Sörgel et al. 2002).

\section{Acrylamide and oxidative stress}

Oxidative stress occurs when the rate of generation of free oxygen radicals (ROS) is larger than the rate of their neutralization. An excess of free radicals may cause oxidation of biological molecules namely lipid peroxidation, oxidation of enzymes and oxidation of DNA bases. This leads to damage to cell organelles, impaired cell metabolism, DNA fragmentation and cell death. Free radicals take part in pathogenesis of numerous diseases including diabetes, neurodegeneration, diseases of cardiovascular system, neoplasm formation (Rahman et al. 2012, Greń 2013). Under normal physiological conditions, the occurrence and metabolism of free radicals is controlled by antioxidative system which is composed of enzymatic and nonenzymatic antioxidants. Major enzymatic antioxidants include superoxide dismutase (SOD) catalyzing dismutation of superoxide anion to molecular oxygen and hydrogen peroxide; catalase (CAT) catalyzing the decomposition of hydrogen peroxide; glutathione peroxidase (GPx) catalyzing reduction of hydrogen peroxide accompanied by oxidation of the reduced glutathione (GSH). Nonenzymatic antioxidants like reduced glutathione, vitamins, thioredoxin, $\alpha$-tocopherol etc., take part in neutralization of free radicals by donation of electrons (Lobo et al. 2010).

There is evidence to suggest increased generation of free radicals and hydroperoxides accompanied by lipid peroxidation in animals exposed to acrylamide (Prasad and Muralidhara 2012). Increased activity of SOD in blood plasma, liver, testes, kidneys and brain of acrylamide exposed rats hint at increased rate of formation of superoxide anion in the whole organism (Yousef and El-Demerdash 2006). Other studies indicated increased activity of GPx accompanied by depletion of GSH which suggest adaptation of the antioxidative system to increased $\mathrm{H}_{2} \mathrm{O}_{2}$ generation in different structures of neural system in rats (Zhu et al. 2008). In general, depletion of GSH is a common phenomenon in animals treated with acrylamide. The depletion of GSH results from higher rate of its consumption in reactions with hydrogen peroxide (Zhu et al. 2008, Kopańska et al. 2015) and conjugation with acrylamide and/or glycidamide in the phase II reactions catalyzed by glutathione s-transferase (Paulsson et al.
2005). Glutathione is a major cell antioxidant whose shortage may be an additional factor contributing to redox imbalance. Indeed, the data suggest that $\mathrm{AA}$ may overwhelm the antioxidative system and cause symptoms of oxidative stress. For instance Yousef and El-Demerdash (2006) indicated systemic increase of concentration of thiobarbituric acid reactive substances in rats orally exposed to acrylamide. In similar fashion, our team observed increased concentration of malondialdehyde in different brain areas of rats intraperitoneally injected with AA solutions, all to suggest redox imbalance and increased peroxidation of lipids (Kopańska et al. 2015). Moreover, Zhu et al. (2008) found decreased activity of SOD in neural system of rats after 10 weeks of exposure to acrylamide applied every third day. This effect probably resulted from oxidation of SOD by excessively generated superoxide ion.

All of these imply that acrylamide induces higher activity of antioxidative system, and that high doses of acrylamide applied for longer time period induce symptoms of oxidative stress. The data presented here were obtained in animal studies using the acrylamide doses in the range $0.5 \mu \mathrm{g}$ to $40 \mathrm{mg} / \mathrm{kg}$ body weight. First symptoms of affected redox balance were found after 10 weeks of exposure to acrylamide doses of $25 \mu \mathrm{g} / \mathrm{kg}$ b.w. (Yousef and El-Demerdash 2006). Such doses are only several times higher than the maximum acrylamide doses possibly ingested with food by some human populations. Thus it is not clear whether people exposed to acrylamide concentrations typically occurring in food will experience affected regulation of redox reactions.

\section{Genotoxicity and cytotoxicity of acrylamide}

Oxidative imbalance induced by exposure to acrylamide may lead to cytotoxic and genotoxic effects. Free radicals may cause damage to mitochondria and other cell organelles. They induce apoptosis and cause oxidation of DNA bases, leading to fragmentation of the double strand. All of these may cause cell death or neoplastic transformation (Valko et al. 2004). The ROS related mechanism of cytotoxicity and/or mutations is attributed to all the factors capable of inducing oxidative stress. On the other hand, acrylamide is known to exhibit more specific effects on cells. AA was found to form 7-formamidoethyl adducts with guanine. The formation of adducts with other acid bases is also probable, although they show decreasing stability as 
guanine $>$ adenine $>$ uracil (Solomon et al. 1985, Shelkovsky et al. 2002). The product of acrylamide biotransformation, glycidamide, shows higher affinity to acid bases of nucleic acids than acrylamide. Nonetheless, both compounds were found to form the strongest adducts with guanine at N-7 position (Atay et al. 2005). N7-dG-glycidamide is the main DNA adduct. It has large pro-mutagenic properties because of formation of G-T transversions during DNA replication (Besaratinia and Pfeifer 2004). In embryonic fibroblasts of transgenic Big Blue mice exposed in vitro to acrylamide dose of $320 \mu \mathrm{M}, \mathrm{A}-\mathrm{G}$ transitions and $\mathrm{G}-\mathrm{C}$ transversions were found (Besaratinia and Pfeifer 2003). In human lymphocytes, exposure to AA caused DNA strand to break, induced caspases-3 activity, and apoptosis. Moreover, AA was found to disrupt DNA repair (Blasiak et al. 2004).

The studies over genotoxicity of chronic doses of acrylamide indicated significant increase of glycidamide-DNA adducts in spermatocytes of mice exposed to doses of acrylamide as low as $0.01 \mu \mathrm{g}$ per $\mathrm{ml}$ of drinking water given every day for 9-12 months. These animals also showed increased number of incidences of double-strand breaks in DNA of the germ cells (Nixon et al. 2012).

The genotoxic effects of acrylamide indicate that it may also play significant role in neoplastic transformation. The carcinogenic potency of acrylamide was proven by Friedman's et al. (1995) studies. The study was conducted in males and females of Fischer 344 rats. AA was administered in the drinking water, throughout the 106-week period, at the dose ranging from 0.1 to $0.3 \mathrm{mg} / \mathrm{kg}$ b.w. per day. The results indicated a significant increase in the frequency of thyroid follicular cell adenomas and adenocarcinomas in male rats from the high-dose group. Moreover, that group witnessed incidence of mesothelioma of the tunica of the testes. The females group saw a significant increase in the frequency of mammary gland fibroadenoma and adenocarcinomas. This study also reported the occurrence of the thyroid and mammary glands tumors after exposure to AA (Friedman et al. 1995). Another long term studies were performed in females of swiss-ICR mice. The specimens were exposed to AA doses going from 2.5 to $50.0 \mathrm{mg} / \mathrm{kg}$ b.w., administered orally, every second day. After 1-year observation, the development of skin tumor in mice exposed to the highest AA doses was observed (squamous cell papilloma and carcinoma). Moreover, incidences of lung cancer were noted (Bull et al. 1984).

The pro-oncogenic activity of acrylamide in humans is not evident. Epidemiological studies did not indicate any relation between exposure to acrylamide and cancer incidences in human (Marsh et al. 1999). On the other hand, the doses of acrylamide inducing genotoxic effects in animals well correspond with the AA doses ingested by high consumers of food containing acrylamide. This is why European Union classification of Carcinogens placed acrylamide in the second category, as carcinogen and mutagen (Szczerbina 2005). Moreover, International Agency for Research on Cancer classified AA as a potentially carcinogenic substance for people (IARC 1994).

\section{Reproductive toxicity of acrylamide}

As a low molecular weight compound easily dissolving in water, acrylamide passes through the placenta in animals and human organism. It was also found in breast milk of women. Thus it may have the influence on the normal prenatal and early postnatal development of infants (Sörgel et al. 2002). Nonetheless, the data on the risk of the harmful influence of acrylamide on the early development of human has not been assessed so far.

The food frequency questionnaire estimated medial acrylamide intake in pregnant women as $33.7 \mu \mathrm{g} /$ day. The median excretion of acrylamide based on urine metabolites in this group of women was $11.2 \mu \mathrm{g} /$ day (range: 3.3-75.6 $\mu \mathrm{g} /$ day). Assuming that about $55 \%$ of acrylamide is depurated in urine as mercapturic acid metabolites, this would correspond to a median exposure of $20.3 \mu \mathrm{g} /$ day (Brantsæter et al. 2008). According to the above calculation, the maximum exposure to acrylamide in pregnant women may be as high as $137.5 \mu \mathrm{g} /$ day. It was estimated that about $50 \%$ of dietary acrylamide may be transferred through the placental blood into the embryo (Sörgel et al. 2002). According to the questionnaire-based studies, the main dietary sources of acrylamide to pregnant women were potato crisps, crisp bread, biscuits, breakfast cereals and bakery products (Brantsæter et al. 2008).

The embryotoxic effects of acrylamide were studied in animal models. Exposure of pregnant females of rodents to AA doses $\geq 5 \mathrm{mg} / \mathrm{kg}$ b.w./day, administered orally, resulted in increased post-implantation loss of embryos and decreased number of live pups. Exposure of pregnant females to higher doses of AA $(\leq 15 \mathrm{mg} / \mathrm{kg}$ 
b.w./day) resulted in reduced pup weight and survival (NTP 2011). Interesting studies over acrylamide influence on embryonic and early postnatal development of rats were performed by El-Sayyad et al. (2011). In this study, pregnant females were orally exposed to high acrylamide doses of $30 \mathrm{mg} / \mathrm{kg}$ b.w. from day 6 of gestation until parturition and throughout lactation. The young pups derived from acrylamide exposed females had lower body size and weight and lower brain size in comparison to control animals. They also suffered from muscular dystrophy and ultrastructural changes in cerebral cortex.

The reproductive toxicity of acrylamide is also manifested by its influence on animal male infertility. According to Scientific Committee on Food (SCF 2002), the impaired fertility may involve affected sperm count and sperm motility parameters. The increased number of glycidamide-DNA adducts and fragmentation of DNA in germ cells of male mice exposed chronically to low AA doses was proved by Nixon et al. (2012). This suggests increased risk of DNA lesions in male reproductive material and their possible introduction into zygote. Indeed, it was found that exposure of male rats to acrylamide doses of $19 \mathrm{mg} / \mathrm{kg}$ for eight days and next mated to unexposed females led to reduced fertility rates and increased frequency of resorption of embryos (Sakamoto and Hashimoto 1986). Moreover, exposure of rats to acrylamide (dose of $100 \mathrm{ppm}$ ) resulted in disrupted mating performance, ejaculatory processes and subsequent transport of sperm (Zenick et al. 1986).

\section{Neurotoxicity of acrylamide}

The only toxic effects of acrylamide well documented in human were manifested by peripheral neuropathy related to occupational exposure (Pennisi et al. 2013). Symptoms of peripheral neuropathy were also described in animal studies. In monkeys, chronic oral exposure to AA doses of $10 \mathrm{mg} / \mathrm{kg}$ b.w./day for up to 12 weeks was associated with clinical signs of peripheral neuropathy like muscle weakness or ataxia of limbs (SCF 2002). In rats, neurotoxic AA effects were manifested by abnormal gait, shown as foot splay, ataxia and weakness of the hindlimb skeletal muscle. Complete paralysis of hindlimbs occurred after 10 weeks of AA administration in a dose of $40 \mathrm{mg} / \mathrm{kg}$ b.w. every second day. The behavioral effects were accompanied by serious alteration of electrophysiology of the sciatic nerve which may suggest alteration of the myelin capsule and/or altered activity of axolemmal Na/K-ATPase (Zhu et al. 2008).

In animal studies, toxic effects of acrylamide were also indicated in central nervous system. Rat pups born by mothers exposed to acrylamide ( $30 \mathrm{mg} / \mathrm{kg}$ b.w.) and fed with milk from lactating females exposed to acrylamide showed serious ultrastructural changes in cerebral cortex. They were manifested by massive increases of pyknotic neuronal cells separated by widened spaces, increased number of apoptotic cells, death of Purkinje cells and granular neuronal cells (El-Sayyad et al. 2011). It is reasonable to suggest that ultrastructural changes in brain may be followed by functional effects. Our team has indicated decreased activity of acetylcholinesterase, an enzyme playing regulatory function in cholinergic transmission, in cerebrum, cerebellum and medulla oblongata of mice exposed to acrylamide doses of 20 and $40 \mathrm{mg} / \mathrm{kg}$ for $24 \mathrm{~h}, 48 \mathrm{~h}$ and 8 days. This may hint at longer time of residence of acetylcholine in cholinergic synapses and higher excitation of cholinergic nerves engaged in memory formation, behavior, muscle controlling, controlling of autonomic functions etc. (Kopańska et al. 2015).

There are probably several mechanisms of acrylamide neurotoxicity. It is generally accepted that the most important one is related with conjugation of AA with cysteine residues of presynaptic membrane proteins engaged in neurotransmitter release. Consequently, the flow of nerve impulses may be inhibited, coupled with subsequent degeneration of neurons (LoPachin and Barber 2006, Pingot et al. 2013). Important role in neurotoxicity of acrylamide is probably played by oxidative stress. Zhu et al. (2008) indicated that peripheral neuropathy and altered electrophysiology of the sciatic nerve were accompanied by the symptoms of redox imbalance. Similarly, in our studies, the affected activity of acetylcholinesterase were accompanied by depletion of albumins and -SH group concentrations and elevated content of malondialdehyde in brain of mice exposed to AA which also suggest induction of redox imbalance (Kopańska et al. 2015).

The redox imbalance in brain of animals exposed to acrylamide is an important observation as free radicals are known to contribute to neurodegeneration. The increased level of malondialdehyde, the product of peroxidation of lipids, was found in erythrocytes, blood serum and neurofibrillary tangles in brains of Alzheimer's disease patients (Matveychuk et al. 2011). Assuming that neurodegeneration results from cumulative 
damage to neuronal cells induced by free radicals (Praticò 2005), it may be reasonably established that food ingredients capable of inducing redox imbalance in brain may participate in etiology of neurodegenerative diseases. The relation between the consumption of acrylamide-rich food and risk of neurodegeneration has not been studied so far, although this seems to be an interesting problem for toxicological and epidemiological studies.

\section{Conclusion}

Acrylamide belongs to the most common toxins in human diet. It shows relatively high concentrations in asparagine rich foods processed at high temperature. Its mean consumption depending on the population and age of consumers usually reaches approximately $1 \mu \mathrm{g} / \mathrm{kg}$ body weight daily, although in high AA consumers its maximum intake may be above $8 \mu \mathrm{g} / \mathrm{kg}$ body weight per day. This corresponds with the AA doses inducing peroxidation of lipids and DNA lesions in long term animal studies. Genetic disorders may affect male fertility, embryonic and fetal development and neoplastic transformation. On the other hand, realistic data indicating the relation between consumption of AA rich food and health risk for human are still missing. The only well documented health disorders occurred as a result of occupational exposure and were manifested by peripheral neuropathy symptoms.

\section{Conflict of Interest}

There is no conflict of interest.

\section{Acknowledgements}

This work was supported by the Slovak Research and Development Agency under the contract no. SK-PL2015-0032.

\section{References}

ATAY NZ, ÇALGAN D, ÖZAKAT E, VARNALI T: Acrylamide and glycidamide adducts of guanine. $J$ Mol StrucTHEOCHEM 728: 249-251, 2005.

BARBER DS, HUNT JR, EHRICH MF, LEHNING EJ, LOPACHIN RM: Metabolism, toxicokinetics and hemoglobin adducts formation in rats following subacute and subchronic acrylamide dosing. Neurotoxicology 22: 341-353, 2001.

BCS (BUREAU OF CHEMICAL SAFETY): Health Canada's revised exposure assessment of acrylamide in food. Food Directorate, Health Products and Food Branch, 1-19, 2012, www.hc-sc.gc.ca

BECALSKI A, LAU B, LEWIS D, SEAMAN S: Acrylamide in foods: occurrence, sources, and modeling. J Agric Food Chem 51: 802-808, 2003.

BESARATINIA A, PFEIFER GP: Weak yet distinct mutagenicity of acrylamide in mammalian cells. $J$ Natl Cancer Inst 95: 12, 2003.

BESARATINIA A, PFEIFER GP: Genotoxicity of acrylamide and glycidamide. J Natl Cancer Inst 96: 1023-1029, 2004.

BFR (FEDERAL INSTITUTE FOR RISK ASSESSMENT): Assessment of acrylamide intake from foods containing high acrylamide levels in Germany, 2003, http//www.bfr.bund.de

BLASIAK J, GLOC E, WOZNIAK K, CZECHOWSKA A: Genotoxicity of acrylamide in human lymphocytes. Chem Biol Interact 149: 137-149, 2004.

BRANTSÆTER AL, HEUGEN M, DE MUL A, BJELLAAS T, BECHER G, VAN KLAVEREN J, ALEXANDER J, MELTZER HM: Exploration of different methods to assess dietary acrylamide exposure in pregnant women participating in the Norwegian Mother and Child Cohort Study (MoBa). Food Chem Toxicol 46: 2808-2814, 2008.

BULL RJ, ROBINSON M, STOBER JA: Carcinogenic activity of acrylamide in the skin and lung of Swiss-ICR mice. Cancer Lett 24: 209-212, 1984.

CARERE A: Genotoxicity and carcinogenicity of acrylamide: a critical review. Ann Ist Super Sanita 42: 144-155, 2006.

CLAEYS W, BAERT K, MESTDAGH F, VERCAMMEN J, DAENENS P, DE MEULENAER B, MAGHUINROGISTER G, HUYGHEBAERT A: Assessment of the acrylamide intake of the Belgian population and the effect of mitigation strategies. Food Addit Contam Part A Chem Anal Control Expo Risk Assess 27: 1199$1207,2010$. 
CLAUS A, CARLE R, SCHIEBER A: Acrylamide in cereal products: a review. J Cereal Sci 47: 118-133, 2008.

DYBING E, SANNER T: Risk assessment of acrylamide in foods. Toxicol Sci 75: 7-15, 2003.

EDEGAARD RV, GRANBY K, FRANDSEN H, THYGESEN J, SKIBSTED LH: Acrylamide in bread: effect of prooxidants and antioxidants. Eur Food Res Technol 227: 519-525, 2008.

EFSA (EUROPEAN FOOD SAFETY AUTHORITY): Acrylamide carcinogenicity - new evidence in relation to dietary exposure. Scientific Colloquium, Summary Report 11: 1-27, 2008.

EFSA (EUROPEAN FOOD SAFETY AUTHORITY): Results on the monitoring of acrylamide levels in food. Scientific Report 285: 1-26, 2009. http://www.efsa.europa.eu/sites/default/files/scientific_output/files/ main_documents/285r.pdf

EL-SAYYAD HI, EL-GAMMAL HL, HABAK LA, ABDEL-GALIL HM, FERNANDO A, GAUR RL, OUHTIT A: Structural and ultrastructural evidence of neurotoxic effects of fried potato chips on rat postnatal development. Nutrition 27: 1066-1075, 2011.

FRIEDMAN M: Chemistry, biochemistry, and safety of acrylamide. J Agric Food Chem 51: 4504-4526, 2003.

FRIEDMAN MA, DULAK LH, STEDHAM MA: A lifetime oncogenicity study in rats with acrylamide. Fundam Appl Toxicol 27: 95-105, 1995.

GIRMA KB, LORENZ V, BLAUROCK S, EDELMANN F: Coordination chemistry of acrylamide. Coord Chem Rev 249: 1283-1293, 2005.

GOFFENG LO, KJUUS H, HEIER MS, ALVESTRAND M, ULVESTAD B, SKAUG V: Colour vision and light sensitivity in tunnel workers previously exposed to acrylamide and N-methylolacrylamide containing grouting agents. Neurotoxicology 29: 31-39, 2008.

GREŃ A: Effects of vitamin E, C and D supplementation on inflammation and oxidative stress in streptozotocininduced diabetic mice. Int J Vitam Nutr Res 83: 168-175, 2013.

HE FS, ZHANG SL, WANG HL, LI G, ZHANG ZM, LI FL, DONG XM, HU FR: Neurological and electroneuromyographic assessment of the adverse effects of acrylamide on occupationally exposed workers. Scand J Work Environ Health 15: 125-129, 1989.

IARC (INTERNATIONAL AGENCY FOR RESEARCH ON CANCER): Some industrial chemicals. Monographs on the Evaluation of Carcinogenic Risk for Chemicals to Humans. Lyon, France. 60: 435, 1994.

JANKOWSKA J, HELBIN J, POTOCKI A: Acrylamide as a foreign substance in food (in Polish). Probl Hig Epidemiol 90: 171-174, 2009.

KERAMAT J, LEBAIL A, PROST C, JAFARI M: Acrylamide in baking products: a review article. Food Bioprocess Tech 4: 530-543, 2011.

KJUUS H, GOFFENG LO, HEIER MS, SJÖHOLM H, OVREBØ S, SKAUG V, PAULSSON B, TÖRNQVIST M, BRUDAL S: Effects on the peripheral nervous system of tunnel workers exposed to acrylamide and N-methylolacrylamide. Scand J Work Environ Health 30: 21-29, 2004.

KONINGS E, BAARS A, KLAVEREN J, SPANJER M, RENSEN P, HIEMSTRA M, KOOIJ JA, PETERS PWJ: Acrylamide exposure from foods of the Dutch population and an assessment of the consequent risks. Food Chem Toxicol 41: 1569-1579, 2003.

KOPAŃSKA M, LUKÁČ N, KAPUSTA E, FORMICKI G: Acrylamide influence on activity of acetylcholinesterase, thiol groups, and malondialdehyde content in the brain of Swiss mice. J Biochem Molec Toxicol 29: 472-478, 2015.

LOBO V, PATIL A, PHATAK A, CHANDRA N: Free radicals, antioxidants and functional foods: impact on human health. Pharmacogn Rev 4: 118-126, 2010.

LOFSTEDT RE: Science communication and the Swedish acrylamide "alarm". J Health Commun 8: 407-432, 2003.

LOPACHIN RM: The changing view of acrylamide neurotoxicity. Neurotoxicology 25: 617-630, 2004.

LOPACHIN RM, BARBER DS: Synaptic cysteine sulfhydryl groups as targets of electrophilic neurotoxicants. Toxicol Sci 94: 240-255, 2006.

MARSH GM, LUCAS LJ, YOUK AO, SCHALL LC: Mortality patterns among workers exposed to acrylamide: 1994 follow up. Occup Environ Med 56: 181-190, 1999.

MATVEYCHUK D, DURSUN SM, WOOD PL, BAKER GB: Reactive aldehydes and neurodegenerative disorders. Bull Clin Psychopharmacol 21: 277-288, 2011. 
MESTDAGH F, CASTELEIN P, PETEGHEM C, MEULENAER B: Importance of oil degradation components in the formation of acrylamide in fried foodstuffs. J Agric Food Chem 56: 6141-6144, 2008.

MOJSKA H, GIELECIŃSKA I: Assessment of exposure of children and youth to acrylamide in fast foods and snacks. Probl Hig Epidemiol 93: 613-617, 2012.

MOLDOVEANU SC, GERARDI AR: Acrylamide analysis in tobacco, alternative tobacco products and cigarette smoke. J Chromatogr Sci 49: 234-242, 2011.

MOORMAN WJ, REUTMAN SS, SHAW PB, BLADE LM, MARLOW D, VESPER H, CLARK JC, SCHRADER SM: Occupational exposure to acrylamide in closed system production plants: air levels and biomonitoring. J Toxicol Environ Health A 75: 100-111, 2012.

MOTTRAM DS, WEDZICHA BL, DODSON AT: Food chemistry: acrylamide is formed in the Maillard reaction. Nature 419: 448-449, 2002.

NIXON BJ, STANGER SJ, NIXON B, ROMAN SD: Chronic exposure to acrylamide induces DNA damage in male germ cells of mice. Toxicol Sci 129: 135-145, 2012.

NTP (NATIONAL TOXICOLOGY PROGRAM): Toxicology and carcinogenesis studies of acrylamide in F344/N rats

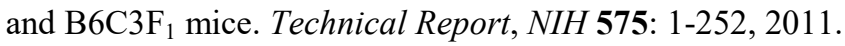

PAULSSON B, RANNUG A, HENDERSON AP, GOLDING BT, TÖRNQVIST M, WARHOLM M: In vitro studies of the influence of glutathione transferases and epoxide hydrolase on the detoxification of acrylamide and glycidamide in blood. Mutat Res 580: 53-59, 2005.

PENNISI M, MALAGUARNERA G, PUGLISI V, VINCIGUERRA L, VACANTE M, MALAGUARNERA M: Neurotoxicity of acrylamide in exposed workers. Int J Environ Res Public Health 10: 3843-3854, 2013.

PINGOT D, PYRZANOWSKI K, MICHAŁOWICZ J, BUKOWSKA B: Toxicity of acrylamide and its metabolite glycidamide (in Polish). Med Pracy 64: 259-270, 2013.

PRASAD SN, MURALIDHARA: Evidence of acrylamide induced oxidative stress and neurotoxicity in Drosophila melanogaster - its amelioration with spice active enrichment: relevance to neuropathy. Neurotoxicology 33 : 1254-1264, 2012.

PRATICÒ D: Peripheral biomarkers of oxidative damage in Alzheimer's disease: the road ahead. Neurobiol Aging 26: 581-583, 2005.

RACHWAŁ D, NEBESNY E: Reduction of acrylamide content in food products (in Polish). Bromat Chem Toksykol 2: 219-227, 2012.

RAHMAN T, HOSEN I, ISLAM MMT, SHEKHAR HU: Oxidative stress and human health. Adv Biosci Biotechnol 3: 997-1019, 2012.

SAKAMOTO J, HASHIMOTO K: Reproductive toxicity of acrylamide and related compounds in mice effects on fertility and sperm morphology. Arch Toxicol 59: 201-205, 1986.

SCF (SCIENTIFIC COMMITTEE ON FOOD): Opinion of the Scientific Committee on Food on new findings regarding the presence of acrylamide in food. SCF/CS/CNTM/CONT/4 Final, Belgium, 3 July 2002. http://ec.europa.eu/food/fs/sc/scf/out131_en.pdf

SCHETTGEN T, ROSSBACH B, KÜTTING B, LETZEL S, DREXLER H, ANGERER J: Determination of haemoglobin adducts of acrylamide and glycidamide in smoking and non-smoking persons of the general population. Int J Hyg Environ Health 207: 531-539, 2004.

SHELKOVSKY V, STEPANIAN SG, GALETICH IK, KOSEVICH MV, ADAMOWICZ L: Modelling of recognition sites of nucleic acid bases and amide side chains of amino acids. Combination of experimental and theoretical approaches. Eur Phys J D 20: 421-430, 2002.

SIROT V, HOMMET F, TARD A, LEBLANC JC: Dietary acrylamide exposure of the French population: results of the second French Total Diet Study. Food Chem Toxicol 50: 889-894, 2012.

SOLOMON JJ, FEDYK J, MUKAI F, SEGAL: Direct alkylation of 2'-doxynucleosides and DNA following in vitro reaction with acrylamide. Cancer Res 45: 3465-3470, 1985.

SÖRGEL F, WEISSENBACHER R, KINZIG-SCHIPPERS M, HOFMANN A, ILLAUER M, SKOTT A, LANDERSDORFER C: Acrylamide: increased concentrations in homemade food and first evidence of its variable absorption from food, variable metabolism and placental and breast milk transfer in humans. Chemotherapy 48: 267-274, 2002. 
SZCZERBINA T: Acrylamide as probable carcinogen in food (in Polish). Kosmos Probl Nauk Biol 54: 367-372, 2005.

TAEYMANS D, WOOD J, ASHBY P, BLANK I, STUDER A, STADLER RH, GONDÉ P, VAN EIJCK P, LALLJIE $\mathrm{S}$, LINGNERT $\mathrm{H}$, LINDBLOM $\mathrm{M}$, MATISSEK R, MÜLLER D, TALLMADGE D, O'BRIEN J, THOMPSON S, SILVANI D, WHITMORE T: A review of acrylamide: an industry perspective on research, analysis, formation, and control. Crit Rev Food Sci Nutr 44: 323-347, 2004.

TAJNER-CZOPEK A, RYTEL E, KITA A, PĘKSA A, MIEDZIANKA J: The influence of parameters of thermal treatment on acrylamide content in selected processed potatoe products (in Polish). Bromat Chem Toksykol 3: 320-325, 2012.

TAREKE E, RYDBERG P, KARLSSON P, ERICSSON S, TORNQVIST M: Analysis of acrylamide, a carcinogen formed in heated foodstuffs. $J$ Agric Food Chem 50: 4998-5006, 2002.

TAREKE E, LYN-COOK B, ROBINSON B, ALI S: Acrylamide: a dietary carcinogen formed in vivo? J Agric Food Chem 56: 6020-6023, 2008.

VALKO M, IZAKOVIC M, MAZUR M, RHODES CJ, TELSER J: Role of oxygen radicals in DNA damage and cancer incidence. Mol Cell Biochem 266: 37-56, 2004.

VESPER HW, BERNERT JT, OSPINA M, MEYERS T, INGHAM L, SMITH A, MYERS GL: Assessment of the relation between biomarkers for smoking and biomarkers for acrylamide exposure in humans. Cancer Epidemiol Biomarkers Prev 16: 2471-2478, 2007.

VIKSTRÖM AC, WARHOLM M, PAULSSON B, AXMON A, WIRFÄLT E, TÖRNQVIST M: Hemoglobin adducts as a measure of variations in exposure to acrylamide in food and comparison to questionnaire data. Food Chem Toxicol 50: 2531-2539, 2012.

YOUSEF MI, EL-DEMERDASH FM: Acrylamide-induced oxidative stress and biochemical perturbations in rats. Toxicology 219: 133-141, 2006.

ZAJĄC J, BOJAR I, HELBIN J, KOLARZYK E, POTOCKI A, STRZEMECKA J, OWOC A: Dietary acrylamide exposure in chosen population of South Poland. Ann Agric Environ Med 20: 351-355, 2013.

ZENICK H, HOPE E, SMITH MK: Reproductive toxicity associated with acrylamide treatment in male and female rats. J Toxicol Environ Health 17: 457-472, 1986.

ZHANG Y, REN Y, ZHANG Y: New research developments on acrylamide: analytical chemistry, formation mechanism, and mitigation recipes. Chem Rev 109: 4375-4397, 2009.

ZHU Y, ZENG T, ZHU Y, YU S, WANG Q, ZHANG L, GUO X, XIE K: Effects of acrylamide on the nervous tissue antioxidant system and sciatic nerve electrophysiology in the rat. Neurochem Res 33: 2310-2317, 2008.

ŻYŻELEWICZ D, NEBESNY E, ORACZ J: Acrylamide - formation, physicochemical and biological properties (in Polish). Bromat Chem Toksykol 3: 415-427, 2010. 